\title{
TEACHING ENGLISH MILITARY TERMINOLOGY IN MILITARY CLASSES
}

\author{
Dariusz BOGUSZ, Maj. PhD \\ Polish Air Force Academy \\ ul. Dywizjonu 303 no 35 \\ 08-521 Dęblin, Poland \\ d.bogusz@wsosp.pl
}

\begin{abstract}
The article highlights the issue of teaching English military terminology in uniformed classes. It draws the conclusions on conducting authorial military terminology syllabus in one of the schools carrying out the pedagogical innovation, which has assumed patronage of Polish Air Force Academy (PAFA). Military classes gained a huge popularity, having met the youth's interest in armed forces they became a key element in national defense education.
\end{abstract}

Keywords: military English, military terminology, military classes, teaching English, STANAG standards

Theconstructofraisingapatriotic societyisadifficultthing to establish in the times of globalization and cosmopolitan values. Current reality is not in favor of getting the society involved in issues concerning the defense of the country. Not everyone is aware of the threats to the national security. Until recently, it was believed that NATO and UE will warrant the security. However, latest events which have happened in Ukraine and immigration crisis showed us once again that security cannot be taken for granted and needs to be constantly taken care of. In those circumstances it is crucial we keep an eye on military classes' practices.

Basic form of engaging the society in actions aiming at defending and securing the country is improving the partnership of the Polish Armed Forces, the nongovernmental organizations and social partners, for instance local government units, universities, which operating areas are linked to the national defense. The awareness of bonds between these institutions is facilitating the professionalization of the army ${ }^{1}$.

The curriculum and extra-curricular activities implemented in military classes are improving citizenship, teaching to have respect for tradition and national symbols, as well as respecting the law. They also prepare students to be more autonomous in choosing the continuation of their higher education in civil and departmental colleges. Another priority of the English military terminology is teaching foreign languages.

The article, based on the conclusions from the original program of the English language teaching related to basic military terminology in upper-secondary schools, is set to answer the question whether teaching military terminology in English in military classes is preparing the youth for serving the Armed Forces in Poland, including the recently established territorial defense troops and national backup forces. It was assumed that teaching English military terminology in military classes contributes to a better preparation for the service

1 A. Leksowska, „Udostępnianie nieruchomości wojskowych organizacjom pozarządowym i innym partnerom społecznym", Civitas et Lex, 2014/2, University of Warmia and Mazury, Olsztyn 2014, p. 31. in professional army. Moreover, it provides more chances for candidates for the officer and non-commissioned schools. Observation and research show the positive influence of executed classes on the education of defense system and carry out the advantages for learners and the defense system itself.

The cooperation between non-governmental organizations and National Defense Department is one of the pillars of creating and carrying out the national defense politics. If organized efficiently it should contribute to, among others, development of coordination and monitoring non-governmental organizations and other social partners when it comes to creating the social background of the Armed Forces and defense, cooperating in building societal acceptance for military activity, inspiring nongovernmental organizations and other social partners to undertake action for the sake of National Armed Forces, disseminating modern forms of defense education in cooperation with non-governmental organizations and other social partners which implement plans for youth in terms of innovative programs for preparatory military training and safety teaching programs.

One of the basic goals of the cooperation is raising awareness of defensiveness of the country, pro-defense upbringing of the youth, building social background for the Polish Armed Forces and, in this regard, obtaining the best candidates for military service. Classes, which are executed under the proprietary program related to teaching primary military terminology in upper-secondary education, disseminate the knowledge about recent problems of polish defense. Additionally, they develop aptitude and abilities which are helpful if you want to serve in the army.

Familiarity with the language may be the pass to military schools. Courses which realize the pedagogical innovation are the natural source of recruiting candidates for the noncommissioned and officer schools. Recruitment procedure for military schools and academies consists of analyzing the results from one's English matura exam, if not having one, an English test, which one has to pass. Acquaintance with English may help to get salient points. 
Recruitment interview is carried out by the selection committee. The interview is aimed to assess the candidates' predispositions for education in a particular specialization, as well as his/her motivation for military service. During the interview the committee takes into account: performance, attitude, interest (e.g. aviation), sport achievements and language proficiency tests ${ }^{2}$.

Military classes attendance does not guarantee a job within the Armed Forces. Moreover, it does not give one any additional points in the recruitment process. Military schools usually cooperate with military units under collective agreements. The partnership must take place under the rules established by National Defense Department concerning collaboration between non-governmental organizations and other social partners (decision No 187 of the Minister of National Defense) ${ }^{3}$. Being in touch with military schools and units, uniformed schools' students are familiar with requirements regarding the recruitment process for professional soldiers. After completing education in military school, students receive certificates which are confirmation of their trainings. Placing emphasis on physical development as well as on participating in fitness competitions should flourish in creating the perfect candidates. Received certificates, familiarity with the recruiting rules, physical fitness and fluent use of English, in majority of cases, help to obtain a military school student record book or even a job in institutions linked to defensive capabilities.

Besides satisfying the interest in the army, military classes have become an important feature of defense education in Poland. In order to guarantee safety and inviolability of borders to the country, it is crucial the society is prepared to defend the country and knows how to organize befitting structures to do it. That is why the enthusiastic potential of the youth should be made use of. Defense education, regarded as the whole of didactic and pedagogic activities directed at children as well as at teenagers and adults, should aim at achieving permanent changes in the sphere of knowledge, abilities and the value system of citizens. High awareness of defensiveness of the country translates into high capacity of defending one's country. ${ }^{4}$

National Defense department supports the social operations in aid of the defensiveness of the country. Military units cooperate with military classes for the benefit of the defense education. The organizational segments of Ministry of National Defense inspire social partners to operate in the interest of the defensiveness of the country. Additionally, it backs them up in substantive or/and logistic issues, depending on what was included in cooperation agreements and what needs were expressed. Owing to this,

2 Polish Air Force Academy Senate Resolution No 12/LXXXVI/2011, dated 5th May 2011 regarding conditions and procedures recruitment for PAFA first degree studies in 2012/2013.

3 Decyzja Nr 187/MON Ministra Obrony Narodowej z dnia 9 czerwca 2009 r. w sprawie wprowadzenia zasad współpracy resortu obrony narodowej z organizacjami pozarządowymi i innymi partnerami społecznymi. 4 See: P. Rozwadowski, Państwowy Urząd Wychowania Fizycznego i Przysposobienia Wojskowego 1927-1939, Dom Wydawniczy Bellona, Warsaw 2000.

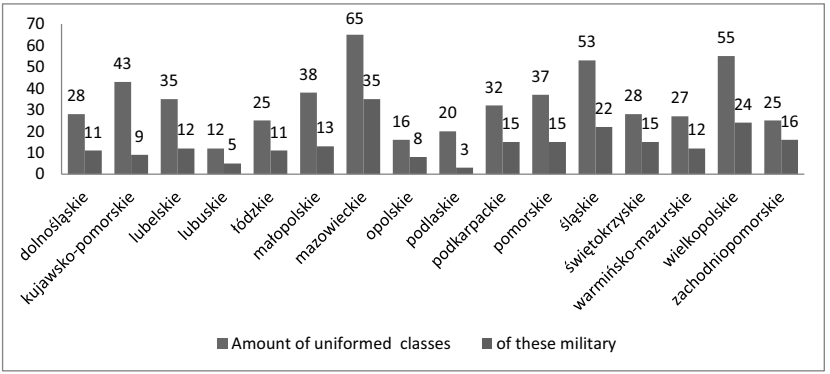

Picture 1. Register of schools attaining pedagogical innovations within defense education (dated 20.06.2016 r.)

Source: www.wojsko-polskie.pl/pl/articles/wspolpraca-wojska-zpartnerami-spolecznymi-j/wspolpraca-ze-szkolami-f2016-05-18/

Curriculum for specialized English related to basic military terminology meets the expectations of young people attending military classes. Research, carried out by the author of the curriculum, show that about 90 percent of young people is interested in learning military terminology in English ${ }^{5}$. This kind of attitude towards uniformed classes is no surprise. In this great global village familiarity with foreign languages is the basis of modern society and the key to development of individuals. Students feel that being fluent in English may provide a better takeoff in their career paths and knowing military terminology might help them in implementing their plans and getting into military university.

Language learning in military classes should be based on young people's needs. It should also enable them to fulfilling their national defense interests and prepare them for international actions and relations. Acquaintance with English is the basic element of communication, and at the same time it helps to get to know customs of an ally. Elaboration and introduction of authorial lingual syllabus is the first step in perfecting the use of military terminology in English in classes with the pedagogical innovation. As the result, defense education will be smoothly developed. Creating territorial defense forces, carrying out a lot of international military exercises and joint trainings for pro-defense organizations' members and soldiers increases the chances of progress for military classes graduates. The members of pro-defense organizations and graduates of uniformed schools will have precedence over others in the Territorial Defense Force (TDF) recruitment process if they signed an agreement concerning the partnership with Ministry of National Defense or a military unit. Knowing English and the terminology should enable classification to that newly created formation.

Ongoing changes present in armed forces demand a new approach to educating and preparing staff. Preparing welltrained specialists in the armed forces demands searching for the enthusiasts in upper-secondary schools. Initiatives

5 M. Kowalska-Jóźwik, Autorski program nauczania języka angielskiego z zakresu podstawowej terminologii wojskowej w klasach szkót ponadgimnazjalnych realizujących Innowację Pedagogiczna o tematyce wojskowej, Ryki 2015 
of engaging the youth in defense-concerning matters, originating from uniformed classes activities, were met with a strong social interest and TDF approval.

The purpose of military classes education is making the students interested in military, increasing their fitness, broadening the knowledge of national security and its defensiveness. Additional extra-curricular activities (for instance drill classes, English classes) and trainings (e.g. parachute trainings, gliding courses, training camps) are organized under the realization of the pedagogical innovative in military classes. Moreover, students are also able to take part in defense and sporting events, meetings with people important for national defense and excursions to interesting places ${ }^{6}$. Military classes students do not hide the fact that serving in uniform is their dream. It is known that there is not enough place to fit all the students, that is why only the best ones will get the chance to study at military universities.

High school graduates, if want to get into officer candidate schools, need to prove themselves by being fit and having good matura exam results. In the recruitment process, not only mathematics and physics results are analyzed in-depth, but also English results are looked into.

In high school English is taught under syllabus approved by Ministry of National Education. The syllabus contains excerpts of vocabulary and grammar which students acquire throughout their high school education. That education will later on become the base for professional terminology.

Since 1999, when Poland joined NATO, English has been taught in officer candidate schools and at training courses. According to STANAG 6001, cadets and soldiers are taught general English, focusing on simple, understandable communication (levels 1-2) and fluent usage of the language (level 3).

Currently, high schools which carry out the pedagogical innovative do not conduct specialist language classes. The authorial syllabus is a response to military student's requests and it is set to acquaint students with issues concerning armed forces. As the result, the innovation will enable teaching a selected material and will increase the graduates' chances for getting to a military school.

In Earl Kajetan Kicki General Education School Complex the pedagogical innovative was introduced in 2008 by Marek Jóźwik, the school's principal, and is continued to this day. Owing to this, a generalpreparatory class was created. It realized the pedagogical innovative and was taken over a Polish Air Force Academy's patronage. The patronage was based on a agreement which sets the rules of cooperation between PAFA and the high school. The agreement states that the cooperation between those two institutions aims to promote knowledge and skills related to national defense and aviation, as well as respect for values shared by the Polish Armed Forces and Ministry of National Education. ${ }^{7}$ The classes were conducted by a delegated PAFA officer.

After consultations with Polish Army officers and conversations with uniformed classes students in Sobieszyn there arose a need for extracurricular activities concerning basic English military terminology.

Authorial military-themed syllabus was formulated to introduce learners to English military terminology. It was carried out on extracurricular activities.

Basic theoretical and practical information were included in the content of teaching. They could be later on developed.

In the research participated 31 learners who attended the extracurricular activities, which made 100 percent of the examined.

The classes were conducted from October to May, in the number of 20 teaching hours. In the classes there participated more than 80 percent of high school No. 1 students and 70 percent of high school No. 2 students. At the end of the classes everyone got a certificate which confirmed finishing the course. To finish the course you had to, first of all, be present at the classes, second of all, take an active part in the classes. After finishing the course you had to take a test. In order to evaluate the course or to modify next editions all students filled in an anonymous questionnaire. The answers has shown that the course has brought expected results. The course attendance proved that people are interested in military terminology. Because of the course, learners could learn new vocabulary and strengthen their knowledge.

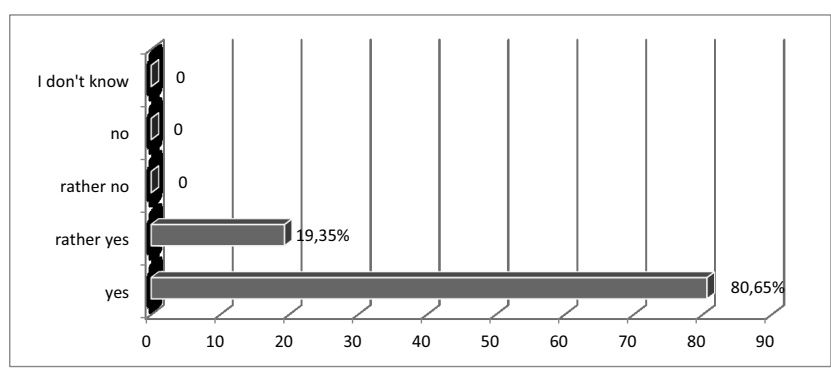

Picture 2. The distribution of answers to the question: did the course impact your lingual development?

Picture No.2 shows the answers concerning impact of the classes on the learners' general lingual development. All the examined stated that their participation in the classes increased their lingual skills. There were no negative answers. More than 80 percent of the examined firmly stated that their lingual skills have improved.

The answers show that the examined did not only strengthen their knowledge of specialized terminology, but also general subjects, such as, grammar or syntax. 


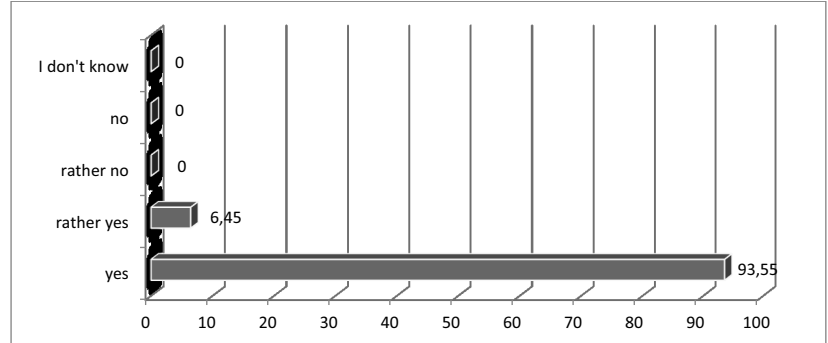

Picture 3. The distribution of answers to the question: did the participation in the course enabled you to familiarize with military issues (in English)?

When it comes to the question about military issues, answers are the same - Picture 3. There were only two answers provided - 'rather yes' and 'yes'. According to the examined, the course met the expectations concerning the military terminology acquaintance. More than 93 percent say that they definitely had a chance to learn more about military issues. Furthermore, 100 percent answered the question positively.

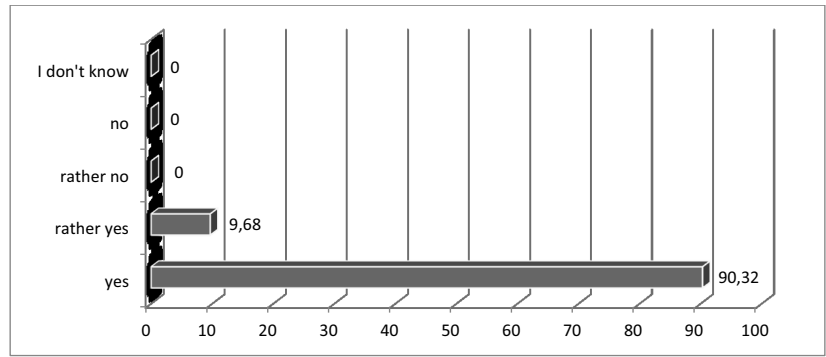

Picture 4. The distribution of answers to the question: did the course help you to get to know the functioning of the Armed Forces of the members of NATO?

Picture 4 clearly shows that a vast majority of the respondents feel that because of the course they got to know the functioning of the Armed Forces of NATO's members. The rules and terms of professional military service abroad, in particular in the structures on NATO, interest young people. Lessons concerning NATO were one of the most active ones. However, students have asked to meet soldiers who have experience with leadership in NATO.

Such distribution of answers may stem from the fact that the teaching aids, which were used in classes concerning NATO, were based on authentic publications, guides, articles and original textbooks used in American and British trainings. ${ }^{8}$ Moreover, youth is interested in the presence of NATO allies in our country. Young people keep up with media reports about their activities during military trainings.

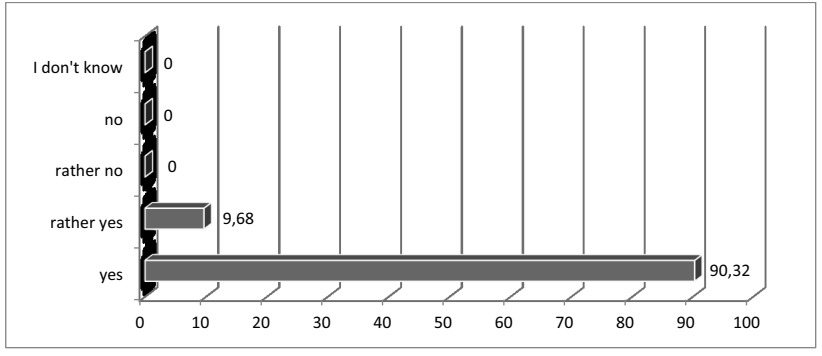

Picture 5. The distribution of answers to the question: did the classes related to English military terminology (choice of the subject) meet your expectations?

With regard to answers above (Picture 5), it should be stated that the responders are satisfied with the choice of the subject of English military terminology. There were no negative answers, furthermore, more than 90 percent stated that the chosen topics exceeded their expectations.

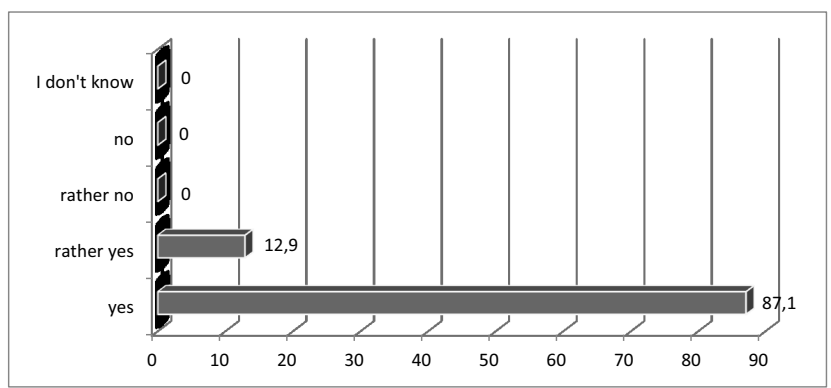

Picture 6. The distribution of answers to the question: will the knowledge you acquired throughout the course be useful in next stages of your education on future job? Will it enable you to fulfill the requirements imposed by the uniformed services' recruitment process?

All of the examined stated that the knowledge they have acquired will be useful in the future. The ones who aim at getting into military school said that the extra military terminology classes may help them to get qualified to uniformed services.

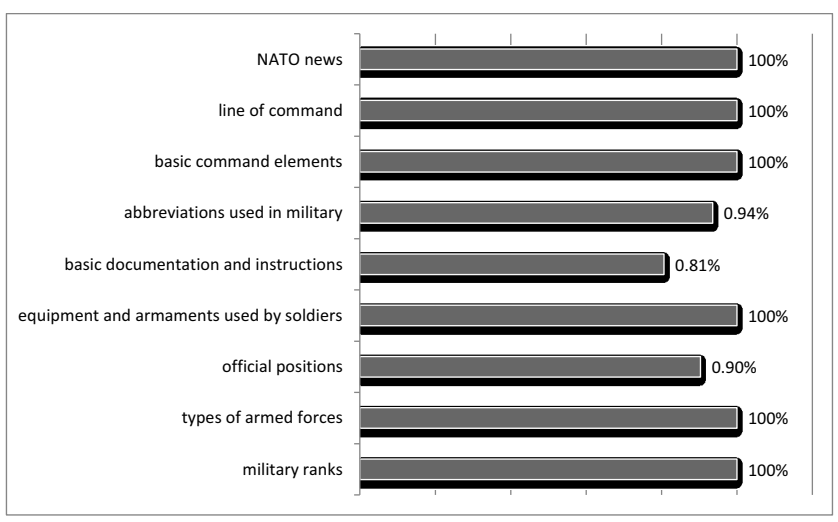

Picture 7. The distribution of answers to the question: in your opinion, which of the subjects conducted at English military terminology classes were most interesting? 
The answers above show that every subject arouse students' interest. Besides 'basic documentation and instruction', 'abbreviation used in military and official soldier positions', the subject were considered $100 \%$ interesting.

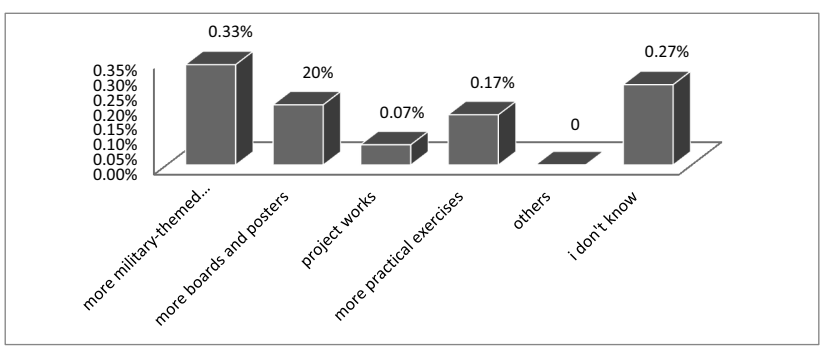

Picture 8. The distribution of answers to the question: What changes in the way of conducting the course should be made?

The answers to question No. 8 indicate that there is a need to make the classes more appealing by showing more military-themed movies, carrying out more practical exercises related to newly-met vocabulary and implementing more course-related boards and posters.

Moreover, the results helped in defining the course requirements concerning the teaching methods. The examined felt that there should more classes devoted to practice, for instance drill classes, shooting exercises and executing commands in English.

The responses of the examined, observations and students' attendance show that English military terminology classes conducted under the military innovative met up the students' expectations. Preliminary research has already shown that there is a need for that type of classes, the answers form questionnaires only reassured the appropriateness of conducting the course. What is important is that the course was only for volunteers, it wasn't compulsory.

Vocational education should be based on active involvement of all the education process participants. The described program was formed on the students' needs, but also on observations made by teachers and military specialists who had experience in serving abroad. In 5 years of launching military innovation, introducing extracurricular classes in Brzozowa high school has adjusted the syllabus to the students' needs (which are labor market's needs). Using the uniformed classes' potential is possible in complicated security milieu. Creating territorial defense is broadening the possibilities of finding a job related to one's interest and field of study. Extension of military school's limit is an opportunity to study in branch schools. Furthermore, the organization of domestically carried out international exercises requires state institutions employees being familiar with military terminology. The program is reaching towards new approach to vocational education. Authorial syllabus was created in collaboration with students and military experts, taking into account abilities of the graduates, military schooling preferences and labor market's needs. Its main emphasis is on practical knowledge. Cooperation based on an agreement with PAFA gives the students access to an advanced didactic base and support of the PAFA officer cadre.

Initiatives which aim at involving young people and society in defense-supporting activities are distinguished. Military classes play a huge part in shaping state-oriented attitude. Young people's activeness and commitment to learning military subjects creates a big probability of developing a new territorial defense system (which once existed, but has become insolvent after the formation of professional army). National Reserve Forces has not filled the gap which was left after abolishing compulsory military service, while the presence of expeditionary military does not release us from building a system which would give us a guarantee of self-reliant defense. The uniformed classes success, the amount of paramilitary groups and the vastness of interest in national security studies give us some hope for developing that system. What is more, opening military universities for civilian students and teaching them in the field of studies which will be useful in jobs related to national defense also show that creating new territorial defense system is more and more possible. PAFA is a good example for this occurrence, for that it licenses pilots or schools navigators and national defense specialists even in civil fields of studies. A good idea was to create military groups in civil fields of studies at General Tadeusz Kościuszko Military Academy of Land Forces in 2012. As the result, students will be able to learn military subjects. It should be though out if those students can be promoted to be reserve soldiers ${ }^{9}$.

\section{CONCLUSIONS}

Units of the Ministry of National Defense, which are held accountable for the cooperation with pro-defense organizations, grand substantial and methodical aid within the development of defense training teaching syllabus and delegate course instructors. Coordination and help from military experts are used to work out the authorial syllabuses, e.g. English and tactics, which are implemented as extra-curricular classes. Activities like these contribute to national defense system development and youth's military system preparation.

Carried out research show that basic English military terminology classes attracted a lot of attention. Students, who participated in those classes, were interested in military issues and were happy to take part in the classes. According to the responders, the classes were conducted in an interesting way. Furthermore, they believe that those classes are necessary. The choice of topics was enjoyed by the students. However, to make the classes even better, there need to be more practical exercises.

Learners, who attended the classes, have mastered basic grammar and vocabulary. Structural material from the first program activities was taken into consideration, so that the classes could extend acquired before lingual knowledge

9 See.: D. Bogusz, „Popularyzacja wiedzy o obronności państwa”, Roczniki Wyższej Szkoły Biznesu i Administracji 10/2014, Łuków 2014. p. 216. 
by, for instance, group conversations, pair work, practicing drill.

Learning the English military terminology gives an opportunity to use it in professional or/and private life. Being familiar with defensive expertise and obtaining certificates which will be helpful in getting into military university are crucial for the students. Participation in the classes helped students to pass NATO's English test and to get to 1111 level in English (under STANAG standards).

\section{REFERENCES}

1. Agreement between Kajetan Kicki, General Education School Complex and PAFA, dated 10.03.2009.

2. Bogusz D., Popularyzacja wiedzy o obronności państwa, Roczniki Wyższej Szkoły Biznesu $i$ Administracji 10/2014, Luków 2014.

3. Decision No. 187/MON of Minister of National Defense, dated 09.06.2009, regarding introducing the rules of cooperation between National Defense Department, non-governmental organizations and other social partners.

4. Kowalska-Jóźwik M., Autorski program nauczania języka angielskiego z zakresu podstawowej terminologii wojskowej w klasach szkól ponadgimnazjalnych realizujacych Innowację Pedagogiczna o tematyce wojskowej, Ryki 2015.

5. Leksowska A., Udostepnianie nieruchomości wojskowych organizacjom pozarzadowym i innym partnerom społecznym, Civitas et Lex 2014/2, University of Warmia and Mazury, Olsztyn 2014.

6. Polish Air Force Academy Senate Resolution No 12/ LXXXVI/2011, dated 5th May 2011 regarding conditions and procedures recruitment for PAFA first degree studies in $2012 / 2013$.

7. www.wojsko-polskie.pl 